\title{
Contribution to the Soil-dwelling Mite Fauna of the Hungarian Agroecosystems (Acari)
}

\author{
J. KONTSCHÁN*, A. ÁCS and A. SUTÁK \\ Plant Protection Institute, Centre for Agricultural Research, Hungarian Academy of Sciences, H-1525 \\ Budapest, P.O. Box 102, Hungary
}

(Received: 20 July 2015; accepted: 8 August 2015)

\begin{abstract}
Numerous different agroecosystems (alfalfa, apple, cereals, oilseed rape, maize, sunflower fields and plantations, a pasture and a compost hill) were investigated on the basis of the soil dwelling mites in two parts of Hungary. Twenty-three species of Mesostigmata, 13 Oribatida, one Astigmata and one Prostigmata are listed from these specific ecosystems, of which nine species, Alliphis halleri (G. and R. Canestrini, 1881); Antennoseius avius Karg, 1976; Antennoseius pannonicus Willmann, 1951; Arctoseius eremitus (Berlese, 1918); Cheiroseius bryophilus Karg, 1969; Leioseius insignis (Hirschmann, 1963); Oppiella loksai (Schalk, 1966); Punctodendrolaelaps fimetarius (Karg, 1965); Rhodacarellus perspicuus Halaśkova, 1958 are new to the Hungarian fauna.
\end{abstract}

Keywords: Acari, soil, agroecosystems, new records, Hungary.

The diversity and the species composition of soil dwelling mites in the agricultural areas are very poorly investigated in Hungary and in other countries as well. The diversity and the role of the mesostigmatan mites are discussed in $\operatorname{Karg}(1968,1978,1986,1993)$, Koehler (1997) and Wissuwa et al. (2012), but our knowledge about other soil dwelling mites of orchards, fields, small private gardens for vegetables and fruits are very insufficient. In addition, several mite species have significant role in the life of soil as biological control agent against nematodes, insect larvae and fungus or they have importance in decomposition of the dead plant materials on the fields.

The last year we started a new project to study the soil dwelling mites in the agroecosystems. Our first steps were the investigation of the Hungarian bamboo plantations in which we found numerous mites species as well (Kontschán et al., 2014, 2015). This study contains our new results of the soil dwelling mites of several different Hungarian agroecosystems.

\section{Materials and Methods}

The collected soils were placed in plastic bags and transported directly to a Berlese-funnel for extraction. After two weeks of extraction, the mites were removed, cleared in lactic acid and later studied. After the investigation of the specimens, the mites were stored in alcohol and deposited in the Plant Protection Institute of the Centre for Agricul-

\footnotetext{
* Corresponding author; e-mail: kontschan.jeno@agrar.mta.hu
} 
tural Research of the Hungarian Academy of Sciences and in the Soil Zoology collection of the Hungarian Natural History Museum. Illustrations were made by using a drawing tube. For the identification of the mites we used the books of Gwiazdowicz (2007), Mahunka (1972), Karg (1993), Olszanowszki (1996), Mašán (2003) and Weigmann (2006), the ecological and distributional data follow Karg (1993) and Mahunka and Mahunka-Papp (2004).

\section{Investigated plantations and fields}

1. Different alfalfa plantations were studied close to Csákvár, Csákberény, Újbarok, Vértestolna in Transdanubian part of Hungary (Fig. 1).

2. Two oilseed rape fields were investigated as well close to Héreg and Söréd, in Transdanubian part of Hungary (Fig. 1).

3. Soil samples were collected in two different maize fields close to Csákvár, Biatorbágy and Környe (Transdanubia), and Nyírtura (Eastern part of Hungary).

4. Young cereals plantations were studied close to Csákberény, Kömlőd, Csókakő in Transdanubian part of Hungary.

5. A sunflower field was studied close to town, Oroszlány.

6. An apple orchard and a pasture were investigated close to Nyírtura (Eastern part of Hungary).

7. Samples of a compost hill and garden soil were collected from a private garden, in village Kék (Eastern part of Hungary).

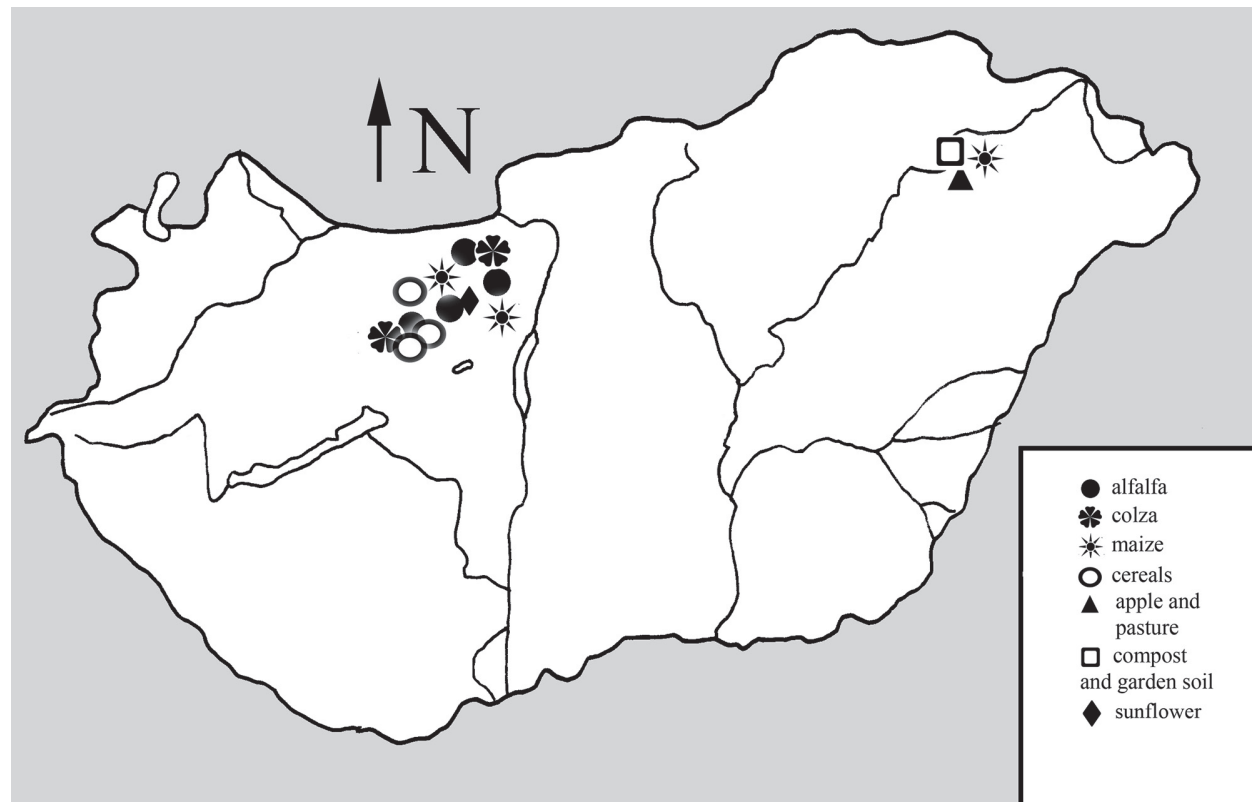

Fig. 1. Investigated plantations and fields 


\title{
Results
}

The 38 mite species were collected in different agroecosystems in Hungary. The 23 species belong to the suborder Mesostigmata, 13 are Oribatida, one is Astigmata and one is Prostigmata. Nine species Alliphis halleri (G. and R. Canestrini, 1881), Antennoseius avius Karg, 1976; Antennoseius pannonicus Willmann, 1951; Arctoseius eremitus (Berlese, 1918); Cheiroseius bryophilus Karg, 1969; Leioseius insignis (Hirschmann, 1963); Oppiella loksai (Schalk, 1966); Punctodendrolaelaps fimetarius (Karg, 1965); Rhodacarellus perspicuus Halaśkova, 1958 are new to the Hungarian fauna.

We found 17 species in the alfalfa plantations, 10 in maize and 9 in cereal fields. Four species were collected in oilseed rape fields and five in apple orchard. Two species occur in garden soil, three in compost hill and sunflower plantation, and two in the studied pasture.

Most frequent Mesostigmata was the Alliphis halleri (Fig. 2a) species which occurred in maize, cereals, alfalfa and garden soils. The species Rhysotritia ardua (Fig. 2b) was the most frequently collected Oribatida in the studied agroecosystems. Common species were also Arctoseius cetratus, Arctoseius venustulus and Bakerdania exigua (Fig. 2c) in the soils of agricultural fields.

\section{List of the collected mites}

\author{
Order Mesostigmata
}

Eviphididae Berlese, 1913

Alliphis halleri (G. and R. Canestrini, 1881)

(Fig. 2a)

Locality: Csákberény, alfalfa; Környe, maize; Kömlőd, cereal; Vértestolna, alfalfa; Nyírtura, maize; Csókakő, cereal; Kék, garden soil; Biatorbágy, maize; Csákvár, sunflower.

Notes: This is the first Hungarian record.

\section{Macrochelidae Graf Vitzthum, 1930 \\ Macrocheles glaber (Müller, 1860)}

Locality: Oroszlány, maize.

Phytoseiidae Berlese, 1916

Amblyseius meridionalis Berlese, 1914

Locality: Nyírtura, maize.

Ameroseiidae Evans, 1963

Amerosieus corbiculus (Sowerby, 1806)

(Fig. 3d)

Locality: Vértestolna, alfalfa; Nyírtura, pasture. 


\section{Family Ascidae Oudemans, 1905}

Asca bicornis (Canestrini and Fanzago, 1887)

(Fig. 3a)

Locality: Kömlőd, cereal.

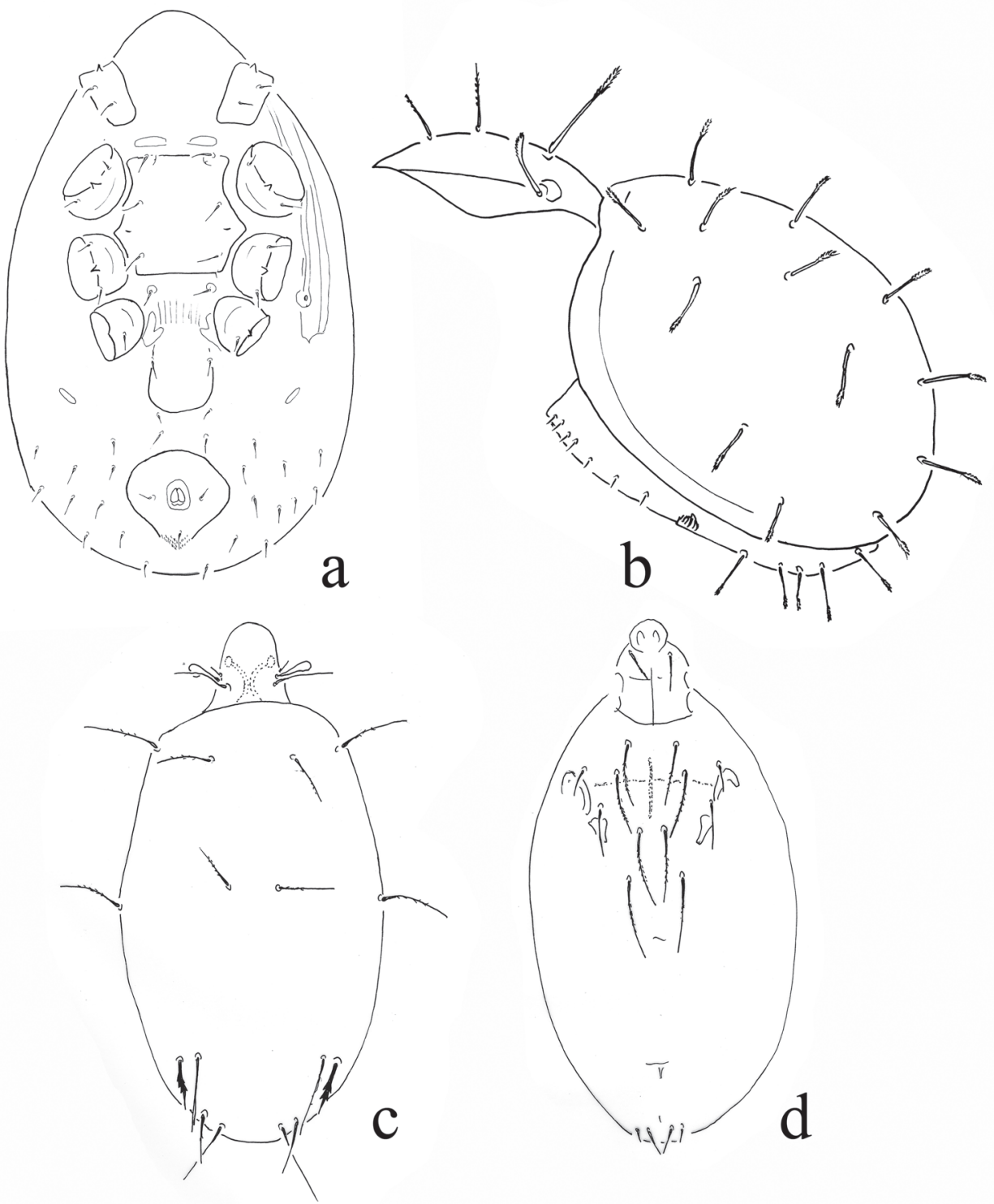

Fig. 2. The most common mites in the studied agricultural areas. a: Alliphis halleri

(G. and R. Canestrini, 1881) ventral view, b: Rhysotritia ardua (C. L. Koch, 1841) lateral view, c: Bakerdania exigua (Mahunka, 1969) dorsal view, d: ventral view 


\section{Arctoseius cetratus (Sellnick, 1940)}

Locality: Nyírtura, maize; Kömlőd, cereal; Söréd, oilseed rape. Csákberény, cereal. Biatorbágy, maize. Csákvár, sunflower.

\section{Arctoseius venustulus (Berlese, 1917)}

Locality: Bokod, cereal. Csókakő, cereal; Csákberény, alfalfa. Biatorbágy, maize. Csákvár, sunflower.

Arctoseius eremitus (Berlese, 1918)

Locality: Csákberény, alfalfa.

Notes: This is the first Hungarian record.

\section{Leioseius bicolor (Berlese, 1918)}

Locality: Csákberény, alfalfa.

\section{Leioseius insignis (Hirschmann, 1963)}

Locality: Nyírtura, maize.

Notes: This is the first Hungarian record.

\section{Cheiroseius bryophilus Karg, 1969}

Locality: Nyírtura, maize.

Notes: This is the first Hungarian record.

\section{Halolaelapidae Karg, 1965}

\section{Antennoseius pannonicus Willmann, 1951}

Locality: Környe, maize.

Notes: This is the first Hungarian record.

\section{Antennoseius avius Karg, 1976}

Locality: Csákberény, alfalfa.

Notes: This is the first Hungarian record.

\section{Rhodacaridae Oudemans, 1902} Punctodendrolaelaps fimetarius (Karg, 1965)

Locality: Vértestolna, alfalfa.

Notes: This is the first Hungarian record.

\section{Rhodacarellus perspicuus Halaśkova, 1958}

(Fig. 3b-c)

Locality: Nyírtura, apple; Biatorbágy, maize.

Notes: This is the first Hungarian record. 

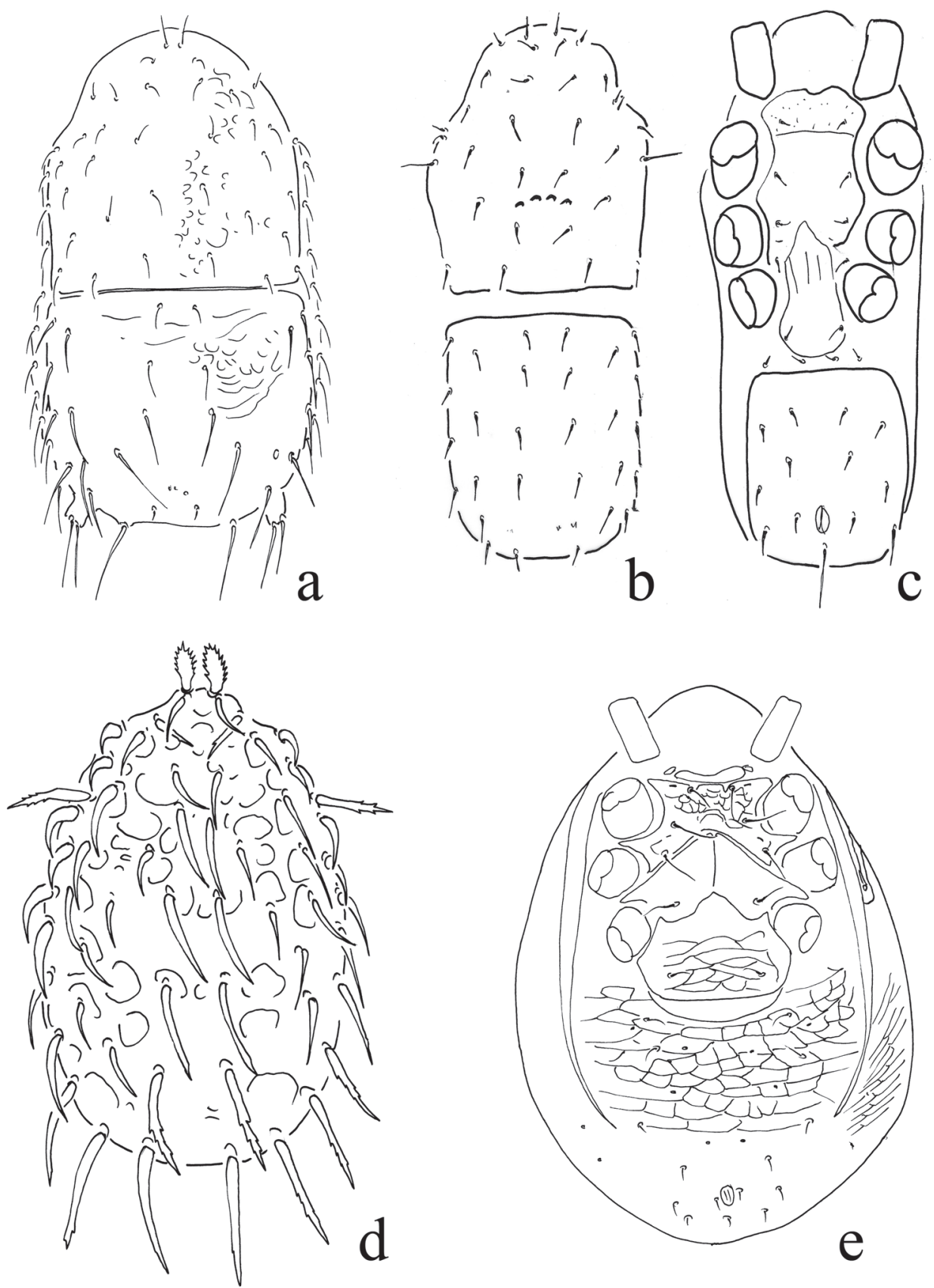

Fig. 3. Mesostigmatans from the agricultural soils. a: Asca bicornis (Canestrini and Fanzago, 1887) dorsal view, b: Rhodacarellus perspicuus Halas'kova, 1958 dorsal view, c: ventral view, d: Amerosieus corbiculus (Sowerby, 1806) dorsal view, e: Holoparasitus calcaratus (C. L. Koch, 1839) ventral view 
Parasitidae Oudemans, 1901

Locality: Csákvár, alfalfa.

Pergamasus crassipes Berlese, 1906

Holoparasitus calcaratus (C. L. Koch, 1839)

(Fig. 3e)

Locality: Nyírtura, apple.

Veigaiaidae Oudemans, 1939

Veigaia planicola (Berlese, 1892)

Locality: Söréd, oilseed rape.

Veigaia nemorensis (C. L. Koch, 1839)

Locality: Nyírtura, apple.

Nenteriidae Hirschmann, 1979

Nenteria breviunguiculata (Willmann, 1949)

Locality: Vértestolna, alfalfa.

Trematuridae Berlese, 1917

Oodinychus karawaiewi (Berlese, 1904)

Locality: Nyírtura, apple.

Leiodinychus orbicularis (C. L. Koch, 1839)

Locality: Kék, compost hill.

Urodinychidae Berlese, 1917

Uroobovella pyriformis (Berlese, 1920)

Locality: Kék, compost hill.

\section{Order Oribatida}

Hypochthoniidae Berlese, 1910

Hypochthonius luteus Oudemans, 1917

Locality: Vértesboglár, cereal.

Epilohmanniidae Oudemans, 1923

Epilohmannia cylindrica (Berlese, 1904)

Locality: Csákberény, alfalfa.

Epilohmannia styriaca Schuster, 1960

(Fig. 4a)

Locality: Csákvár, alfalfa. Csákberény, cereal. 


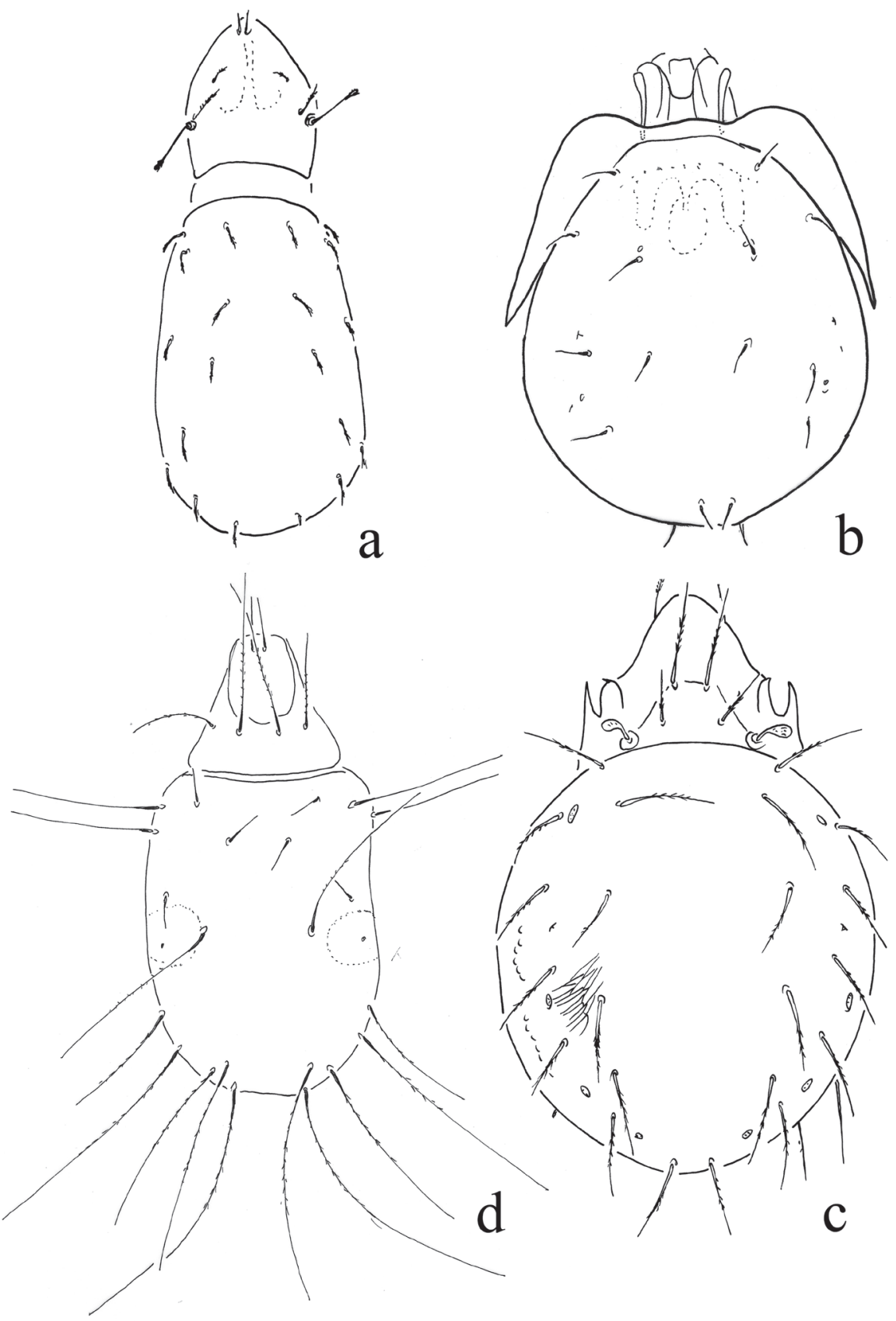

Fig. 4. Mites from the agricultural soils. a: Epilohmannia styriaca Schuster, 1960 dorsal view, b: Peloptulus phaenotus (C. L. Koch, 1844) dorsal view, c: Lucoppia burrowsi (Michael, 1890) dorsal view, d: Tyrophagus longior (Gervais, 1844) dorsal view 
Euphthiracaridae Jacot, 1930

Rhysotritia ardua (C. L. Koch, 1841)

(Fig. 2b)

Locality: Héreg, oilseed rape; Csákberény, alfalfa; Söréd, oilseed rape; Kék, garden soil. Biatorbágy, maize.

\section{Camisiidae Oudemans, 1900}

Camisia biverrucata (C. L. Koch, 1839)

Locality: Csákvár, sunflower.

Oppiidae Grandjean, 1951

Locality: Újbarok, alfalfa.

Oppiella loksai (Schalk, 1966)

Notes: This is the first Hungarian record.

Phenopelopidae Petrunkevich, 1955

Peloptulus phaenotus (C. L. Koch, 1844)

(Fig. 4b)

Locality: Nyírtura, pasture.

Eupelops torulosus (C. L. Koch, 1840)

Locality: Csákvár, maize.

Mycobatidae Grandjean, 1954

Punctoribates sellnicki Willmann, 1928

Locality: Vértestolna, alfalfa; Csókakő, cereal.

Oribatulidae Thor, 1929

Lucoppia burrowsi (Michael, 1890)

(Fig. 4c)

Locality: Újbarok, alfalfa.

Oribatula pannonica Willmann, 1949

Locality: Újbarok, alfalfa.

Zygoribatula exarata (Berlese, 1916)

Locality: Csákberény, alfalfa.

Zygoribatula cognata (Oudemans, 1902)

Locality: Vértesboglár, cereal. 


\section{Suborder Prostigmata}

\section{Pygmephoridae Cross, 1965 \\ Bakerdania exigua (Mahunka, 1969)}

(Fig. 2c-d)

Locality: Csákberény, cereal; Vértesboglár, cereals; Söréd, oilseed rape; Kömlőd, cereal; Nyírtura, apple.

\section{Astigmata/ Cohort Astigmatina}

Acaridae Latreille, 1802

Tyrophagus longior (Gervais, 1844)

(Fig. 4d)

Locality: Környe, maize; Kék, compost hill.

\section{Discussion}

The mesostigmatan mite, Alliphis halleri, was the most common in the studied agroecosystems; this species was found in nine different plantations in Hungary. Koehler (1997) and Wissuwa et al. (2012) presented another Alliphis species (A. siculus Oudemans, 1905) from the agricultural soils, which may be is a misidentification of the A. halleri (see Halliday, 2010). Two Arctoseius species (A. venustulus and A. cetratus) were collected in several different fields and plantations in the investigated agroecosystems. These species are very common in the disturbed habitats, like the agricultural soils (Koehler 1997; Wissuwa et al., 2012). The most of mesostigmatans feed on nematodes and other small insect larvae in the soils, which can be very frequent in the agricultural soils and they can be important prey of the found Mesostigmata.

The oribatid mites have important role in the decomposition of the dead plants and in the soil formation and they usually can feed on decaying plant material and organic matters in the agricultural soils. The agricultural soils usually are poor in the organic material; therefore the species number and the frequency of the oribatid species are lower than mesostigmatans. The Rhysotritia ardua species was collected in higher number in the studied agroecosystems, this species usually occurs in other unstable habitats and other plantations (Kontschán et al., 2015) as well.

The pygmephorid, Bakerdania exigua species are discovered and described from Hungary by Mahunka (1969), therefore it was a surprise that this rare species occurred very often in the agricultural soils.

The most species rich plantation was the alfalfa fields with 17 collected species. The alfalfa plantation elevates the nitrogen content in the soils; this effect can have an important role in the mite diversity of the agricultural soils. 


\section{Acknowledgement}

This research was supported by OTKA 108663.

\section{Literature}

Gwiazdowicz, D. J. (2007): Ascid mites (Acari, Mesostigmata) from selected forest ecosystems and microhabitats in Poland. Wydawnictwo Akademii Rolniczej, Poznań, pp. 1-248.

Halliday, B. R. (2010): Revision of the Australian Eviphididae (Acari: Mesostigmata). Zootaxa 2596, 1-60.

Karg, W. (1968): Bodenbiologische Untersuchungen über die Eignung von Milben, insbesondere von parasitiformen Raubmilben, als Indikatoren. Pedobiologia 8, 30-39.

Karg, W. (1978): Milben als Indikatoren zur Optimierung von Pflanzenschutzmassnahmen in Apfelintensivanlagen. Pedobiologia 18, 415-425.

Karg, W. (1986): Vorkommen and Ernährung der Milbencohors Uropodina Kramer (Schildkrötenmilben) sowie ihre Eignung als Indikatoren in Agroökosystemen. Pedobiologia 29, 285-295.

Karg, W. (1993): Raubmilben. Acari (Acarina), Milben, Parasitiformes (Anactinochaeta), Cohors Gamasina Leach. Die Tierwelt Deutschland 59, 1-523.

Koehler, H. H. (1997): Mesostigmata (Gamasina, Uropodina), efficient predators in agroecosystems. Agric. Ecosyst. Environ. 62, 105-117.

Kontschán, J., Ács, A. and Neményi, A. (2014): Adatok a magyarországi bambuszok atkáihoz. [Data on the mite (Acari) fauna of bamboos in Hungary]. Növényvédelem 50, 339-343.

Kontschán, J., Ács, A., Wang, G-Q. and Neményi, A. (2015): New data to the mite fauna of Hungarian bamboo plantations. Acta Phytopathol. et Entomol. Hung. 50, 77-83.

Mahunka, S. (1969): Sechs neue Milben-Arten aus der Familie Pyemotidae (Acari, Trombidiformes). Acarologia, 11, 527-536.

Mahunka, S. (1972): Tetűatkák - Tarsonemina. In: Magyarország Állatvilága (Fauna Hungariae), XVIII. 16. Akadémiai Kiadó, Budapest, pp. 1-215.

Mahunka, S. and Mahunka-Papp, L. (2004): A Catalogue of the Hungarian oribatid mites (Acari: Oribatida). In: Cs. Csuzdi and S. Mahunka (eds): Pedozoologica Hungarica, No. 2. Hungarian Natural History Museum and Systematic Zoology Research Group of the Hungarian Academy of Sciences, Budapest, pp. 1-363.

Mašán, P. (2003): Macrochelid Mites of Slovakia (Acari, Mesostigmata, Macrochelidae). Institute of Zoology, Slovak Academy of Sciences, Bratislava, pp. 1-149.

Olszanowszki, Z. (1996): A monograph of the Nothridae and Camisiidae of Poland (Acari: Oribatida: Crotonioidea). Genus (Wrocław), Supplement: pp. 1-201.

Weigmann, G. (2006): Hornmilben (Oribatida). Die Tierwelt Deutschland 76, 1-520.

Wissuwa, J., Salamon, J. A. and Frank, T. (2012): Effects of habitat age and plant species on predatory mites (Acari, Mesostigmata) in grassy arable fallows in Eastern Austria. Soil Biol. Biochem. 50, 96-107. 
